'’Luulen, että kouluttajien yksi keskeinen tehtävä on kertoa, ettei kaikkea voi saavuttaa kouluttamalla. Loogisen ajattelun rinnalla ihmisessä vaikuttavat esteettinen ja eettinen minä. Myös ne säätelevät tiedon valintaa ja tapaa havainnoida maailmaa. Koulutuksen keskeinen arvo on nostaa elämän esteettinen ja emotionaalinen puoli tiedon rinnalle, sillä kenties vain vaatimaton osa tiedostamme välittyy numeroiden ja kirjainten kautta."

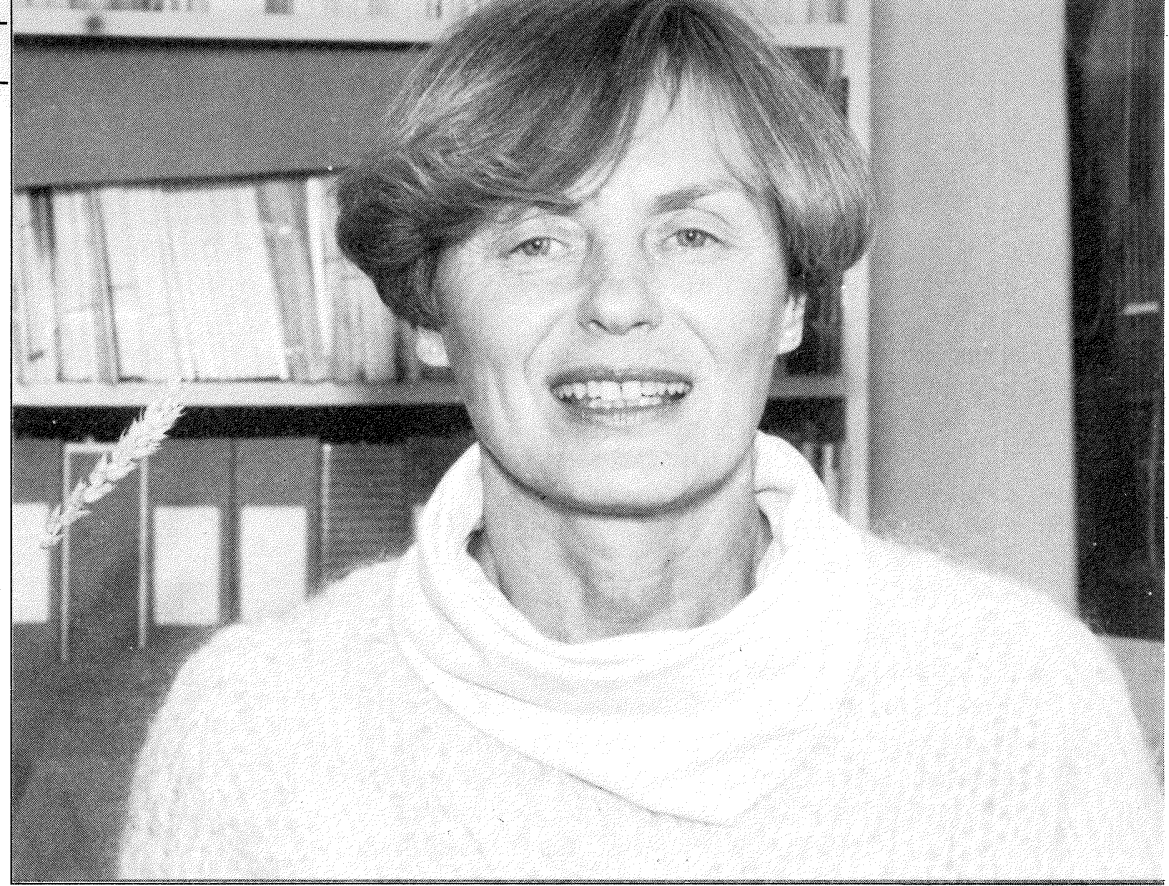

Jaana Venkula:

\title{
TODELLINEN KANSANKIRKKOMME ON TIETEEN IHANNOINTI
}

Jaana Venkula on näkyvä 'matkalukkari' seminaareissa ja konferensseissa. Suomalaisille aikuiskouluttajille ja koulutussuunnittelijoille hän puhui haastattelumme aiheesta Suomen Kaupunkiliiton aikuiskoulutuskonferenssissa Lahdessa.

Venkula on kehitellyt ja tuonut esiin ajatteluaan mm. Tiedepolitiikka-lehdessä, jota kehittämässä hän on ollut aina vuodesta 1984 lähtien, päätoimittajana vuodet 1987-91. Hänen toteuttamansa lehdet tunnettiin pirteinä ja mielenkiintoisina. Hän toimi myös Edistyksen Päivien suunnittelijana ja primus motorina samoina vuosina. Hänen lisensiaattityönsä käsittelee tietämisen taitoja.

Jaana Venkulan varsinainen työ on Helsingin yliopiston tieteentutkimuksen assistentuuri, joka on perustettu opiskelijoiden lahjoitusvirkana.
Tästä työstään hän sai viime keväänä vuoden 1990 tiedonjulkistamispalkinnon sekä vuotta aiemmin yliopistonsa tiedotuspalkinnon. Tiedonjulkistamispalkinnon yhtenä perusteena oli se, että hän on tuonut uusia teoreettisia näkökulmia tieteiden väliseen yhteistyöhön.

\section{Todellinen muutos} ei ole ennustettavissa

'’Positivistinen ja empiristinen suunta tieteessä on tuonut mukanaan sen, että tietona pidetään loogista ja mitattavaa tietoa. Olemme harjaantuneet etsimään kaiken takaa syitä ja seurauksia, logiikkaa", Venkula sanoo.

Hän on valmis asettamaan kyseenalaiseksi kaiken takaa löytyvän logiikan yksinkertaisesti ym- 
märrettynä sekä ennustettavuuden. Onhan valtaosa henkisestä työstä ennustettavuuden ulkopuolella. On myös asioita, joissa ennustaminen on tekemiselle este. Kaikki päämäärät eivät ole saavutettavia, vaan vain suuntaa-antavia.

"'Todellinen muutos ei ole ennustettavissa", Jaana Venkula täsmentää.

Venkula kärjistää tieteen kaikkivoipaisuuden kritiikkinsä myös näin: 'Maailmalle ei olisi kovinkaan suuri vahinko, jos tutkimustoiminta pysäytettäisiin vaikkapa vuodeksi!' Tuo vuosi voitaisiin hänen mukaansa käyttää tähän asti saatujen tutkimustulosten ymmärtämiseen. Jos tutkimus sivuuttaa nyt elämän 'irrationaaliset' ilmiöt, kääntyisikö huomio 'tutkimuksen sapattivuonna' näihin tieteen katveisiin tai etsisikö ihminen tietoa itsestään, itsensä sisältä?

"'Pari tuntia konsertissa tai osallistuminen jumalanpalvelukseen voi saada ihmisessä aikaan enemmän kasvua kuin koulutuksen tuoma tieto", hän sanoo. Jumalanpalvelus on yksi tie traditioon, kulttuuriperintöön. Jokainen ihminen tarvitsee mahdollisuuden kasvaa kiinni johonkin traditioon ja sitä tietä toisten traditioiden kunnioittamiseen.

"'Suomessa pidetään nolona puhua vakavassa mielessä uskonnosta. Kuitenkin ilmennämme kulttuuria tai jätämme ilmentämättä jokaisella teollamme tai tekemättä jättämisellä. Jätämme sillä tavalla itse kukin jälkeemme historiaa." Venkula näkee kosketuksemme kulttuuriin hyvin kirjallisena. Meiltä puuttuvat moniin muihin maihin verrattuna vanha arkkitehtuuri, vanhat traditiot ja yksinkertaiset arjen tavat, jotka estäisivät meitä tulemasta 'tietäviksi barbaareiksi'.

\section{Tarvitsemme enemmän yleissivistystä}

Venkulan pitää myös erikoispätevyyttä yliarvostettuna - seikkaa, jonka Reijo Wilenius on nähnyt tärkeänä siksi, että jokaisen minälle ja omanarvontunnolle on hyvä tuntea osaavansa jonkin asian todella hyvin, olevansa jossakin pätevä.

Erikoisosaamisen rinnalle - vaan ei sijalle Venkula nostaisi paremman yleissivistyksen. $\mathrm{Mm}$. pyrkimys ihmismielen tuntemukseen ja parempi filosofian tuntemus kuuluvat yleissivistyneen ihmisen tunnusmerkkeihin. Nämä Venkula heittäisi koulutuksen haasteiksi, yhdeksi sen keskeisimmistä tehtävistä. 'Yleissivistys ei suinkaan ole sa- ma asia kuin humanismi. Yleissivistys on muun kuin oman erikoisosaamisen tuntemusta. Se on esimerkiksi sitä, että humanisti tuntee tekniikka ja tekniikan ihminen humanismia."

'’Pidän myös tärkeänä, että koulutus kehittää meissä muutosvalmiuksia."

\section{Uudet valmiudet muutoskykyisyyteen}

Mitä ovat sitten uudet taidot ja valmiudet, jotka varmistavat yksilön muutoskykyisyyden ja samalla tuovat yhteiskunnalle parhaan hyödyn?

Assistentti Jaana Venkula luettelee seuraavia seikkoja: ensiksikin jo mainitun tunneherkkyyden lisäksi tiedollisuuden ja informaation suhteellisen (vain suhteellisen) merkityksen oivaltamistaidon, taidon nähdä ilmiöiden uusia, ei-totunnaisia yhteyksiä, kyvyn reagoida nopeasti, kaikkien mentaalisten osajärjestelmien vahvistamisen, loogisten suhteiden tajun kehittämisen, suunniteltavissa ja ei-suunniteltavissa olevien asioiden erottamisen taidon, pitkäjänteisyyden mentaalisen järjestelmän eri ulottuvuuksilla sekä konemaisten ja prosessuaalisten ilmiöiden erottelukyvyn.

Mentaalisilla ihmismielen osajärjestelmillä tarkoitetaan (1) empiiristä eli omien kokemusten ymmärtämistä ja hyväksikäyttöä, (2) eettistä järjestelmää eli vastuuntuntoa, (3) esteettistä tajuntaa eli harmonisen muodon tajua, (4) emotionaalista eli liikkeellepanevaa puolta ihmisessä sekä (5) episteettistä eli tiedollista vahvistumista.

, 'Koulutuksen on toisessa ääripäässä oltava jopa erikoistuneempaa kuin nykyään. Mutta toisessa, nykyään unohdetussa päässä erinäiset ihmisten omaa toimintaa, ajattelua ja historiaa kuvaavat filosofiset seikat on hallittava nykyistä paremmin", hän sanoo. 